\title{
Human hybridoma and recombinant Pritumumab antibodies for treatment of human solid tumors
}

\author{
Rishab Gupta*, Mark Glassy \\ From Society for Immunotherapy of Cancer 29th Annual Meeting \\ National Harbor, MD, USA. 6-9 November 2014
}

Pritumumab is a natural human IgG1 kappa antibody that has been derived from a $B$ cell isolated from regional draining lymph node of a cervical carcinoma patient. Specificity analysis of the antibody with human tissues showed the target antigen, altered tumor-associated vimentin, to be highly restricted to various epithelial cancers and not normal cells and tissues. In various Phase II clinical trials in Japan 249 patients with brain cancer were treated with the antibody. Overall response rate was between 25-30\%, a 9-fold increase over standard care, with several survivors beyond 5-years post-treatment. Patients were on a low dose regimen of $1 \mathrm{mg}$ given twice a week for a course of 24 weeks, suggesting Pritumumab to be safe and effective in patients with brain cancer. However, the yield from human-hybridoma was only about 1 picogram per cell per day. Therefore, there is a pressing need to produce adequate amount of GMP grade Pritumumab in a cost effective manner. The GPEx ${ }^{\circledR}$ technology of Catalent was adapted to develop a Pritumumab-secreting Chinese hamster ovary $(\mathrm{CHO})$ cell line. This involved construction and cloning of heavy and light chain DNAs into an expression vector and transduced into HEK 293 cells that constitutively produce the MLV gag, pro, and pol. The Pritumumab cell line was made by performing multiple rounds of transduction (multiplicity of $>1000$ retrovector particles/cell) of the GPEx ${ }^{\circledR}$ parental cell line $(\mathrm{GCHO})$ with retrovector made from the gene construct developed to express the Pritumumab antibody light and heavy chains. Five independent transductions were performed: two LC and three HC. Limiting dilution method was used to establish cloned cell lines. Top clones were selected based on antibody titer as determined by Protein A HPLC using a generic IgG standard. Single copies of genes were inserted efficiently in unique locations throughout the genome of the $\mathrm{CHO}$ cells to obtain

Nascent Biotech, Inc., San Diego, CA, USA

Submit your next manuscript to BioMed Central and take full advantage of:

- Convenient online submission

- Thorough peer review

- No space constraints or color figure charges

- Immediate publication on acceptance

- Inclusion in PubMed, CAS, Scopus and Google Scholar

- Research which is freely available for redistribution 